\title{
Genetic and Phenotypic Parameters of Body Weight in Ettawa Grade Goats
}

\author{
F. Hasan ${ }^{\mathrm{a}, \mathrm{b}}$, Jakaria ${ }^{\mathrm{b}, *}$, \& A. Gunawan ${ }^{\mathrm{b}}$ \\ aMajor Program of Animal Production and Technology, Faculty of Animal Science, Graduate School, \\ Bogor Agricultural University \\ ${ }^{b}$ Department of Animal Production and Technology, Faculty of Animal Science, Bogor Agricultural University \\ Jln. Agatis, Kampus IPB Darmaga, Bogor 16680, Indonesia \\ (Received 03-03-2014; Reviewed 25-03-2014; Accepted 26-04-2014)
}

\begin{abstract}
The aim of this study was to estimate genetic and phenotypic parameters of growth traits consisting of birth weight (BW), weaning weight (WW), 6 mo body weight (6WM), 12 mo body weight (12WM), and 18 mo body weight (18WM) of Ettawa Grade goats. The number of goat used to determine growth traits of BW, WW, 6WM, 12WM, and 18WM were 316; 316; 259; 259 and 165 heads, respectively. Data were analyzed using General Linear Model (GLM) to identify non-genetic effect. Estimation of genetic and phenotypic parameters including heritability, repeatability, genetic and phenotypic correlation were calculated using Restricted Maximum Likelihood and GLM. Genetic trends were calculated using the regression of mean breeding values on birth year. The results showed that parity and type of birth had significant $(\mathrm{P}<0.05)$ influence on all growth traits. Estimated heritability of birth, weaning, $6 \mathrm{WM}, 12 \mathrm{WM}$, and $18 \mathrm{WM}$ were $0.54 \pm 0.12 ; 0.35 \pm 0.07 ; 0.37 \pm 0.09 ; 0.68 \pm 0.16$ and $0.63 \pm 0.19$, respectively. Estimated repeatability of WW, $6 \mathrm{WM}, 12 \mathrm{WM}$ and $18 \mathrm{WM}, \mathrm{WW}, 6 \mathrm{WM}$, $12 \mathrm{WM}$ and $18 \mathrm{WM}$ were $0.98 \pm 0.01 ; 0.97 \pm 0.01 ; 0.94 \pm 0.03 ; 0.71 \pm 0.12$ and $0.91 \pm 0.04$, respectively. The genetic trends for traits of $\mathrm{BW}$ and 18MW were decreased fluctuatively. However, the WW, 6MW, 12MW were increased fluctuatively. The high and positive genetic correlations between all growth traits and 12WM traits in this study indicated that selection for high 12WM will improve genetic merit in Ettawa Grade goats.
\end{abstract}

Key words: body weight, EBV, Ettawa Grade goat, genetic and phenotypic parameters

\section{ABSTRAK}

Penelitian ini bertujuan untuk mengetahui parameter genetik dan fenotipik sifat pertumbuhan pada waktu lahir (BL), sapih (BS), 6 bulan (B6), 12 bulan (B12) dan 18 bulan (B12) pada kambing peranakan ettawa. Total data yang digunakan untuk menentukan BL, BS, B6, B12 dan B18 masingmasing 316; 316; 259; 259 dan 165 ekor. Analisis general linear model (GLM) digunakan untuk mengkaji pengaruh non-genetik. Parameter fenotipik dan genetik yang meliputi nilai heritabilitas, ripitabilitas dan korelasi genetik dihitung melalui analisis restricted maximum likelihood dan GLM. Selanjutnya untuk mengetahui pola genetik sifat pertumbuhan dihitung melalui analisis regresi rataan nilai pemuliaan terhadap tahun kelahiran. Hasil penelitian menunjukkan bahwa semua sifat pertumbuhan dipengaruhi $(\mathrm{P}<0,05)$ paritas dan tipe kelahiran. Nilai heritabilitas $B L$, BS, B6, B12 dan B18 yang diperoleh masing-masing adalah 0,54 $\pm 0,12 ; 0,35 \pm 0,07 ; 0,37 \pm 0,09 ; 0,68 \pm 0,16$ ;dan 0,63 $\pm 0,19$. Nilai ripitabilitas BL, BS, B6, B12 dan B18 yang diperoleh masing-masing adalah $0,98 \pm 0,01 ; 0,97 \pm 0,01 ; 0,94 \pm 0,03 ; 0,71 \pm 0,12 ;$ dan $0,91 \pm 0,04$. Pola genetik sifat pertumbuhan bobot lahir dan 18 bulan menunjukkan fluktuasi yang cenderung menurun. Hal berbeda ditunjukkan BS, B6 dan B12 yang menunjukkan fluktuasi cenderung meningkat. Korelasi genetik dan fenotipik sifat pertumbuhan kecuali pada BS dengan B12 menunjukkan korelasi tertinggi dengan kisaran antara 0,65-0,92. Tingginya nilai parameter genetik dan fenotipik antara sifat pertumbuhan dengan B12 mengindikasikan bahwa seleksi terhadap B12 akan efektif dalam perbaikan mutu genetik pada kambing peranakan ettawa.

Kata kunci: bobot badan, EBV, kambing Peranakan Ettawa, parameter genetik dan fenotipik

*Corresponding author:

E-mail: jakaria_karman@yahoo.co.id 


\section{INTRODUCTION}

Ettawa Grade goats are one of several Indonesian local goats that plays major role in meat and milk production (dual purpose). Ettawa Grade goats are descended originally from crossing between the Kacang and Ettawa goats (Sodiq, 2012). This breed has a larger body frame, long hanging ears, a convex face, larger horns and excellent body profile (Sodiq \& Abidin, 2010). The population of goat in Indonesia was recorded 18.576.192 in 2013 (Direktorat Jenderal Peternakan, 2013). Most population of Ettawa Grade goats was concentrated in Kaligesing Purworejo Central Java Province. Faster growth rate is a very important trait while meat production is the target. In addition, growth traits are effectively affected program selection because of moderate to higher heritability (Zhang et al., 2009).

Genetic and phenotypic parameters estimation of growth traits of different goat breeds have been reported by several studies (Shrestha \& Fahmy, 2007; Boujenane \& El-Hazzab, 2008; Zhang et al., 2009; Al-Saef, 2013). Al Saef (2013) reported heritability of birth and weaning weight in Syrian Damascus and Boer goat were 0.41 and 0.21, respectively. Zhang et al. (2009) obtained heritability of birth weight and weaning weight in Boer goat were 0.30 and 0.23 , respectively. The heritability estimated of 18 months of age weight $(18 \mathrm{WM})$ in Dwarft African goat was 0.63 (Bosso et al., 2007). Another factor has to be considered when selecting for growth traits were repeatability, genetic and phenotypic correlation (Mokhtari \& Rashidi, 2010). Snyman \& Olivier (1999) reported repeatability of body weight was 0.63 . Bosso et al. (2007) reported genetic correlation between WW and W360 in Dwarft goat was 0.74 . The high and positive genetic correlations implies that they are all being controlled by similar genes and thus selection for any one of these traits would lead to positive changes in the other. Apart from this part, annual genetic trend for growth traits should be monitored overtime to check the accuracy of the genetic prediction made and identification direction genetic change (Intaratham et al., 2008). That is why for designing local goat such as Ettawa Grade goats, improvement of genetic program are very important to realize. However, information of genetic parameter such as heritability related to growth trait for Indonesian local goat such as Ettawa Grade goat are very rare. Therefore, the estimation of genetic and phenotypic parameter for growth traits is important in designing breeding program aim at maximizing genetic improvement. The aim of this study was to estimate genetic analysis of growth trait of Ettawa Grade goat in Breeding Center at Pelaihari, South Kalimantan province.

\section{MATERIALS AND METHODS}

\section{Data Collection}

The data used in this study were collected between 2007 and 2011 from Breeding Center of Ettawa Grade goat in South Kalimantan Province. A total of 316 kids consisting of 138 males and 178 females were used in this research. The traits analyzed included: body weight growth traits at birth (BW), weaning (WW), 6 mo (6WM), $12 \mathrm{mo}(12 \mathrm{WM})$ and $18 \mathrm{mo}(18 \mathrm{WM})$. The records number of BW, WW, 6WM, 12WM and 18WM were 316; 316; 25; 259 and 165 heads, respectively.

\section{Data Analyses}

Non-genetic effect. Growth traits included for this study were $\mathrm{BW}, \mathrm{WW}, 6 \mathrm{WM}, 12 \mathrm{WM}$ and $18 \mathrm{WM}$. All traits were analyzed using General Linear Model (GLM) procedure (SAS 9.2) (Steel \& Torrie, 2005).

$$
\mathrm{Y}=\mu+\mathrm{ri}+\mathrm{si}+\mathrm{pi}+\mathrm{qi}+\mathrm{ti}+\mathrm{e}
$$

where:

$\mathrm{Y}=\mathrm{BW}, \mathrm{WW}, 6 \mathrm{WM}, 12 \mathrm{WM}$ and $18 \mathrm{WM}$

$\mu=$ overall mean

ri = the effect sex of kid (male, female)

si $=$ the effect of birth type (single, twins, triplets)

pi $=$ the effect of parity $(1,2,3)$

qi $=$ the effect of year birth $(2007,2008,2009,2010,2011)$

$\mathrm{ti}=$ the effect of season (dry, rainy)

$\mathrm{e}=$ random error

The same statistical model was used to analyze BW, WW, 6WM, 12WM, and 18WM including 2 way interactions such as year of birth, parity and season. In all statistical model there was no two way interaction, therefore, final models considered only the main effects (Hammoud et al., 2010).

Genetic effect. To evaluate genetic effect of heritability on BW, WW, 6WM, 12WM and 18WM, the data were analyzed by mixed model, sire and dam were included as a random effect in model. The total variance and covariance component were sorted into additive and non-additive components (Meyer, 1992).

$$
Y_{i j k}=\mu+S_{i}+D_{i j}+E_{i j k}
$$

where:

$\mu=$ overall mean

$S_{i}=$ effect of the $i^{\text {th }}$ sire

$D_{i j}=$ effect of the $i j^{\text {th }}$ dam within the $i^{\text {th }}$ sire

$\mathrm{E}_{\mathrm{ijk}}=$ uncontrolled environmental deviations associated with each record which is assumed to be random independent and normally distributed with a mean 0 and a common variance.

Heritability was estimated from sire and dam variance component, according to Becker (1992) as follows:

$$
\mathrm{h}_{\mathrm{d}}^{2}=\frac{4 \delta_{\mathrm{d}}^{2}}{\left(\delta_{\mathrm{s}}^{2}+\delta_{\mathrm{d}}^{2}+\delta_{\mathrm{w}}^{2}\right)}
$$

where:

$\mathrm{h}_{\mathrm{d}}^{2}=$ heritability from dam component

$\delta_{\mathrm{d}}^{2}=$ dam variance component

$\delta_{s}^{2}=$ sire variance component

$\delta_{\mathrm{w}}^{2}=$ within progeny variance component

To estimate standard errors for heritability were analyzed according to Becker (1992): 


$$
\begin{aligned}
& S E\left(h^{2} s+d\right)=\sqrt[4]{\frac{\frac{2}{K_{3}^{2}\left[\frac{M S_{s}^{2}}{S-1+2}+\frac{M S_{d}^{2}}{d-s+2}\right]}}{S^{2} T}} \\
& K_{3}=\frac{1}{S-1}\left[\frac{N-\sum n^{2}-1}{n 1}\right]
\end{aligned}
$$

where:

$\mathrm{MS}_{\mathrm{d}}^{2}=$ mean square dam

$\mathrm{MS}_{s}^{2}=$ mean square sire

$\mathrm{d}_{\mathrm{T}}^{2}=$ total variance

$\mathrm{d}=$ number of dam

$\mathrm{s} \quad=$ number of sire

$\mathrm{K}_{3} \quad$ = number of progeny per sire

Repeatability was estimated from sire variance component, according to Becker (1992) as follows:

$$
\begin{aligned}
& \mathrm{R}=\frac{\delta_{\mathrm{w}}^{2}}{\delta_{\mathrm{w}}^{2}+\delta_{\mathrm{e}}^{2}} \\
& \delta_{\mathrm{e}}^{2}=\mathrm{MS}_{\mathrm{e}} \text { dan } \delta_{\mathrm{w}}^{2}=\frac{\mathrm{MS}_{\mathrm{w}}-\mathrm{MS}_{\mathrm{e}}}{\mathrm{k}_{1}}
\end{aligned}
$$

where:

$\delta_{\mathrm{w}}^{2}=$ with progeny variance component

$\delta_{e}^{2}=$ within progeny variance componet

$\mathrm{MS}_{\mathrm{w}}=$ mean square traits

$\mathrm{MS}_{\mathrm{e}}=$ mean square individual

$\mathrm{k}_{1} \quad$ number of progeny

Phenotypic and genetic correlations were estimated to know relationship among growth traits.

$$
\begin{aligned}
& r_{g}=\frac{\operatorname{cov} 0}{\sqrt{\delta_{o x}^{2} \delta_{\theta y}^{2}}} \\
& r_{p}=\frac{\operatorname{cov} v_{0}+\operatorname{cov}_{\theta}}{\sqrt{\left(\delta_{o x}^{2}+\delta_{\theta x}^{2}\right) \times\left(\delta_{o y}^{2}+\delta_{\theta y}^{2}\right)}}
\end{aligned}
$$

where:

$\mathrm{O} \quad=$ random effects

e $\quad=$ fixed effects

$\mathrm{x}$ or $\mathrm{y}=$ traits a given value refers to $(\mathrm{BW}, \mathrm{WW}, 6 \mathrm{WM}$, $12 \mathrm{WM}$ and $18 \mathrm{WM}$ )

Estimate Breeding Value (EBV) was estimated according to Becker (1992) as follows:
$\mathrm{EBV}=\mathrm{h}^{2} \times \mathrm{DS}$

where:

$\mathrm{h}^{2}=$ heritability

DS $=$ differential selection

Genetic and phenotypic trends were obtained by regression means of predicted breeding values on year of birth and means of traits growth for each trait. Genetic and phenotypic trends analysis according to Filho et al. (2005).

$$
\mathrm{Y}=\mathrm{a}+\mathrm{bX}
$$

where:

$\mathrm{Y}=\mathrm{BW}, \mathrm{WW}, 6 \mathrm{WM}, 12 \mathrm{WM}, 18 \mathrm{WM}$ or breeding value

$\mathrm{a}=$ Intercept

$X=$ year of birth

$\mathrm{b}=$ the regression coefficient for $\mathrm{Y}$ on $\mathrm{X}$

\section{RESULTS AND DISCUSSION}

\section{Comparison of Growth Traits}

Mean along with their standard error (SE) of BW, WW, 6WM, 12WM and 18WM are presented in Table 1. The mean and standard error of BW WW, 6WM, $12 \mathrm{WM}$ and $18 \mathrm{WM}$ were $3.78 \pm 0.03 ; 10.57 \pm 0.11 ; 17.02 \pm 0.25$; $32.01 \pm 0.95$ and $48.66 \pm 0.80 \mathrm{~kg}$, respectively. The mean of BW in this study was higher than value obtained by Sodiq (2012 and 2005) which showed the mean of BW for Ettawa Grade goat in Kaligesing was 3.44 and $3.29 \mathrm{~kg}$. The mean of BW in this study also was higher compared with other goat breed (Al-Shorepy et al., 2002; Rashidi et al., 2011). The mean of BW of Ettawa Grade goat was ranged between 2.63-4.29 kg (Atabany et al., 2001). In contrast with BW, the mean WW and 6WM in this study was lower than previous value reported by Sodiq (2012) in Ettawa Grade goat were 14.75 and 18.86 $\mathrm{kg}$, respectively. However likely BW, the WW and 6WM values also lower compared to other result (Zhang et al., 2009; Rashidi et al., 2011; Al-Saef, 2013). Boujenane \& El-Hazzab (2008) obtained WW value of Draa goat in Morocco was $9.13 \mathrm{~kg}$. Al-Saef (2013) estimated 6WM value of Saudi Aradi goat and their crosses with Syrian Damascus goat was higher than in this study. The 12WM and 18WM mean of Ettawa Grade goat in this study was

Table 1. Number of animals, means, standard error, standard deviations, coefficient of variation, minimum and maximum for Ettawa Grade goat

\begin{tabular}{lcccccrrr}
\hline Traits & Number & Mean & $\begin{array}{c}\text { Standard } \\
\text { error }\end{array}$ & $\begin{array}{c}\text { Standard } \\
\text { deviation }\end{array}$ & $\begin{array}{c}\text { Coefficient of } \\
\text { variation }\end{array}$ & Min & Max \\
\hline BW & 316 & 3.78 & 0.03 & 0.59 & 15.54 & 2.20 & 5.60 \\
WW & 316 & 10.57 & 0.11 & 1.89 & 17.93 & 5.60 & 15.30 \\
6WM & 259 & 17.02 & 0.25 & 4.06 & 23.86 & 7.00 & 25.00 \\
12WM & 259 & 32.01 & 0.95 & 15.34 & 36.92 & 11.00 & 58.00 \\
18WM & 165 & 48.66 & 0.80 & 10.27 & 21.11 & 24.00 & 65.00 \\
\hline
\end{tabular}

Note: $\mathrm{BW}=$ growth traits at birth, $\mathrm{WW}=$ growth traits at weaning, $6 \mathrm{WM}=$ growth traits at $6 \mathrm{mo}, 12 \mathrm{WM}=$ growth traits at $12 \mathrm{mo}, 18 \mathrm{WM}=$ growth traits at $18 \mathrm{mo}$. 
32.01 and $48.66 \mathrm{~kg}$, respectively. The mean of $12 \mathrm{WM}$ in this study was higher than those reported by Bosso et al. (2007) who obtained mean 360 day of age weight in Dwarf goat was $8.04 \mathrm{~kg}$. However, the BW value was lower compared with Boer goat (Zhang et al., 2009). This may be due to the breed factor and effect of environment (Zhang et al., 2009).

\section{Non-Genetic Effect}

Least square means (LSM) and standard errors (SE) for $\mathrm{BW}, \mathrm{WW}, 6 \mathrm{WM}, 12 \mathrm{WM}$, and $18 \mathrm{WM}$ in various fixed effect are given in Table 2. Sex of kid birth had significant effect on $\mathrm{BW}, \mathrm{WW}$ and $6 \mathrm{WM}(\mathrm{P}<0.01)$ but no significant effect on $12 \mathrm{WM}$ and $18 \mathrm{WM}$. This result was in agreement which describing that sex had highly significant influence on pre-weaning and growth rate (Browning et al., 2004; Vargas et al., 2007; Wenzhong et al., 2005; Mioč et al., 2011). In the contrary, sex of kid birth had significant effect on $18 \mathrm{MW}$ and $24 \mathrm{MW}$ in Angora goats (Liu et al., 2005). This might be attributed to different physiological processes in the two sexes. According to endocrine system, estrogen hormone has a limited effect for growth in females. That was one reason why females have smaller body than males (Baneh \& Hafezian, 2009). The effect of parity had no significant on BW, but it had significant effect on WW, 6WM, 12WM and 18WM $(\mathrm{P}<0.01)$. Zhang et al. (2009) reported that the effect of parity had significant on BW $(\mathrm{P}<0.01)$. The effect of parity decreased on parity 1 to 2 , but increased on parity 2 to 3 for BW. It effect increased with increasing parity for $\mathrm{WW}, 6 \mathrm{WM}, 12 \mathrm{WM}$ and $18 \mathrm{WM}$ on parity 1 to 2 and 3 , respectively. The parity of dam effect may be explained by the better development of dam's uterus with increasing parity and age (Zhang et al., 2009; Valencia et al., 2007).

The effect of birth type was significant $(\mathrm{P}<0.01)$ effect on BW, 12WM and 18WM, but had no significant effect on WW and 6WM. Sodiq (2012) reported that birth type was significant effect on BW, 30WD, 60WD, 90WD and 120WD in Ettawa Grade goat. These result agree with previous studies in other breeds by several authors Zhang et al. (2009) on Boer goat, Mandal et al. (2006) on Muzaffarnagari sheep, Liu et al. (2005) on Angora goat, Zhou et al. (2003) on Mongolia cashmere goats in China, Al-Shorepy et al. (2002) on Emirati goat. Single born kids in this study was larger than twins and triplets on BW, but it was lower than twins and triplet on WW, 6WM, $12 \mathrm{WM}$, and 18WM. Zhang et al. (2008) reported that single born was larger than twins and triplets in Boer goat. Growth advantage of single in early period might result from its lower competition for nutrition supply of dam in gestation period than the multiple birth ones (Zhang et al., 2009). Liu et al. (2005) reported that twins and triplets born were lower than single affecting by decreased maternal effect including nursing and milk feeding of the kids by their mothers.

Table 2. Mean along with their standard error (SE) for BW, WW, 6WM, 12WM and 18WM (kg) for Ettawa Grade goat

\begin{tabular}{|c|c|c|c|c|c|}
\hline & \multicolumn{5}{|c|}{ Trait } \\
\hline & $\mathrm{BW}(\mathrm{n})$ & WW (n) & $6 \mathrm{WM}(\mathrm{n})$ & $12 \mathrm{WM}(\mathrm{n})$ & $18 \mathrm{WM}$ (n) \\
\hline \multicolumn{6}{|l|}{ Sex of kid: } \\
\hline Male & $3.87 \pm 0.05^{\mathrm{A}}(138)$ & $10.90 \pm 0.16^{\mathrm{A}}(138)$ & $18.12 \pm 0.38^{\mathrm{A}}(116)$ & $33.20 \pm 1.42(116)$ & $50.41 \pm 1.09$ (79) \\
\hline Female & $3.71 \pm 0.04^{\mathrm{B}}(178)$ & $10.30 \pm 0.14^{\mathrm{B}}(178)$ & $16.41 \pm 0.37^{\mathrm{B}}(143)$ & $30.43 \pm 1.31$ (143) & $47.20 \pm 1.13(94)$ \\
\hline \multicolumn{6}{|l|}{ Parity: } \\
\hline 1 & $3.79 \pm 0.04(172)$ & $11.50 \pm 0.12^{\mathrm{A}}(172)$ & $19.65 \pm 0.27^{\mathrm{A}}(138)$ & $44.27 \pm 1.07^{\mathrm{A}}(138)$ & $52.60 \pm 0.75^{\mathrm{A}}(128)$ \\
\hline 2 & $3.75 \pm 0.06(130)$ & $9.40 \pm 0.14^{\mathrm{B}}(130)$ & $14.19 \pm 0.36^{\mathrm{B}}(107)$ & $17.15 \pm 0.42^{\mathrm{B}}(107)$ & $34.87 \pm 1.04^{\mathrm{B}}(31)$ \\
\hline 3 & $3.99 \pm 0.19(14)$ & $9.30 \pm 0.37^{\mathrm{B}}(14)$ & $14.06 \pm 0.71^{\mathrm{B}}(14)$ & $17.56 \pm 0.92^{\mathrm{B}}(14)$ & $33.74 \pm 1.92^{\mathrm{B}}(6)$ \\
\hline \multicolumn{6}{|l|}{ Birth type: } \\
\hline Single & $4.18 \pm 0.09^{\mathrm{A}}(44)$ & $10.80 \pm 0.28(44)$ & $17.06 \pm 0.62(37)$ & $22.51 \pm 1.49^{\mathrm{C}}(37)$ & $40.62 \pm 2.52^{\mathrm{B}}(17)$ \\
\hline Twins & $3.77 \pm 0.04^{\mathrm{B}}(224)$ & $10.50 \pm 0.13(224)$ & $17.01 \pm 0.34(180)$ & $31.08 \pm 1.22^{\mathrm{B}}(180)$ & $48.53 \pm 1.02^{\mathrm{A}}(109)$ \\
\hline Triplets & $3.46 \pm 0.05^{\mathrm{C}}(48)$ & $10.90 \pm 0.24(48)$ & $18.35 \pm 0.51(42)$ & $42.25 \pm 1.87^{\mathrm{A}}(42)$ & $52.47 \pm 0.90^{\mathrm{A}}(39)$ \\
\hline \multicolumn{6}{|l|}{ Year: } \\
\hline 2007 & $3.72 \pm 0.03(124)$ & $11.90 \pm 0.13^{\mathrm{A}}(124)$ & $20.17 \pm 0.25^{\mathrm{A}}(124)$ & $46.68 \pm 0.89^{\mathrm{A}}(124)$ & $53.31 \pm 0.58^{\mathrm{A}}(123)$ \\
\hline 2008 & $4.04 \pm 0.18(29)$ & $10.40 \pm 0.25^{\mathrm{B}}(29)$ & $15.00 \pm 0.65^{\mathrm{BC}}(3)$ & $22.28 \pm 0.98^{\mathrm{BC}}(3)$ & $37.53 \pm 6.26^{\mathrm{BC}}(3)$ \\
\hline 2009 & $3.66 \pm 0.18(16)$ & $10.10 \pm 0.16^{\mathrm{BC}}(16)$ & $17.85 \pm 1.03^{\mathrm{AB}}(6)$ & $27.33 \pm 3.80^{\mathrm{B}}(6)$ & - \\
\hline 2010 & $3.73 \pm 0.64(35)$ & $10.50 \pm 0.168^{\mathrm{B}}(35)$ & $16.62 \pm 1.08^{\mathrm{B}}(17)$ & $22.85 \pm 1.12^{\mathrm{B}}(17)$ & $40.16 \pm 0.91^{\mathrm{B}}(15)$ \\
\hline 2011 & $3.81 \pm 0.06(112)$ & $9.20 \pm 0.14^{\mathrm{C}}(112)$ & $13.83 \pm 0.32^{\mathrm{C}}(109)$ & $16.27 \pm 0.33^{C}(109)$ & $31.08 \pm 1.01^{\mathrm{C}}(24)$ \\
\hline \multicolumn{6}{|l|}{ Season: } \\
\hline Dry & $3.79 \pm 0.04$ (237) & $11.00 \pm 0.16^{\mathrm{A}}(237)$ & $18.32 \pm 0.30^{\mathrm{A}}(189)$ & $36.35 \pm 1.11^{\mathrm{A}}(189)$ & $52.10 \pm 0.77^{\mathrm{A}}(130)$ \\
\hline Rainy & $3.73 \pm 0.68(79)$ & $9.20 \pm 0.21^{\mathrm{B}}(79)$ & $14.14 \pm 0.37^{\mathrm{B}}(70)$ & $18.80 \pm 0.98^{\mathrm{B}}(70)$ & $35.40 \pm 1.48^{\mathrm{B}}(35)$ \\
\hline
\end{tabular}

Note: means in the same column with different superscript differ significantly $(\mathrm{P}<0.01)$; $\mathrm{n}=$ number of animal; $\mathrm{BW}=$ growth traits at birth; $\mathrm{WW}=$ growth traits at weaning; $6 \mathrm{WM}=$ growth traits at $6 \mathrm{mo} ; 12 \mathrm{WM}=$ growth traits at $12 \mathrm{mo} ; 18 \mathrm{WM}=$ growth traits at $18 \mathrm{mo}$. 
Year of birth had no significant on BW, but it had significant effect on WW, 6WM, 12WM and 18WM $(\mathrm{P}<0.01)$. Year of birth significantly influenced at WW and 18WM with trend of 2007>2010>2008>2009>2011. Year of birth was significantly at 6WM and $12 \mathrm{WM}$ with trend of 2007>2009>2010>2008>2011. Differences result weight in this study between years may be a reflection of differences in feed availability among years due to by variation in total annual precipitation and the distribution of rainfall in breeding centre Ettawa Grade goat. The differences trend of year reflected the variations of natural environments, climate, feeding plane, body conditions of dams, and management for the animals (Zhou et al., 2003; Haile et al., 2009).

Season of birth had no significant on BW, but it had significant effect o WW, 6WM, 12WM and 18WM. Season of birth significantly $(\mathrm{P}<0.01)$ influenced at $\mathrm{WW}$, $6 \mathrm{WM}, 12 \mathrm{WM}$ and $18 \mathrm{WM}$ with a trend was dry $>$ rainy. Live weight (BW, WW, 6WM, 12WM and18WM) of Ettawa Grade goat was born during dry season were always heavier than born during rainy season. Thus, from the results of this study it is evident that kids born in the dry season perform better than in rainy season. Zhang et al. (2009) reported that kids born between May-September were larger than among those born in other season. This variation is due to the availability of pastures to the pregnant dams. Effect season on body weight also reflected management such as mating, housing and feeding for the animals in the local the flock was located (Gunawan \& Noor, 2006). Al-Shorepy et al. (2002) reported that variations among different season might be explained by differences of rainfall which in turn influenced grass production and feed availability.

\section{Genetic Effect}

Heritability. Heritability estimation for BW, WW, 6WM, $12 \mathrm{WM}$, and $18 \mathrm{WM}$ were $0.54 \pm 0.12 ; 0.35 \pm 0.07 ; 0.37 \pm 0.09$; $0.68 \pm 0.16$ and $0.63 \pm 0.19$, respectively. The heritability estimated for body weight traits were moderate to high and range from 0.37 to 0.68 , which indicated a relatively large contribution of additive genetic variance and potentiality for improving body weight in goats by selection. Heritability estimates for BW of Ettawa Grade goat were 0.54 higher than those usually found in literature for tropical goat. Al-Shorepy et al. (2002) reported in Emirati goat used DFREML program was 0.39. Bosso et al. (2007) reported 0.50 for BW of Dwarf goat in West African used ASREML analysis. Estimation heritability of BW was reported in Syrian Damascus goat and Boer goat to be 0.41 and 0.30, respectively (Zhang et al., 2009; Al-Saef, 2013). The heritability estimates generally increased as the age increased from 6WM to 18WM of age. This indicated that gain due to selection in weights at later age could be obtained, as compared to that of earlier age. In the contrary, high estimate of heritability for BW of Aradi goat, Damascus and their crossbreed kids (Al-Saef, 2013).

Estimates of heritability obtained for WW in the present study was 0.35 . This estimate heritability of WW in this study was lower than the value obtained by Zhang et al. (2009) which found that the heritability estimate of WW in Boer goat used Derivative Free
Restricted Maximum Likelihood procedure (DFREML) analysis with range of 0.09 to 0.23 . However, heritability values for WW of Ettawa Grade goat in this study was within the range of published values (Al-Shorepy et al., 2002; Boujenane \& El-Hazzab, 2008; Al-Saef, 2013). Estimation heritability of weaning weight was reported in Emirati and Syrian Damascus goat to be 0.45 and 0.21 respectively (Al-Shorepy et al., 2002; Al-Saef, 2013). Boujenane \& El-Hazzab et al. (2008) obtained heritability for weaning weight used single-trait analysis with range of 0.18-0.65. Genetic improvement for WW has also been attributed to affecting fertility, prolificacy, kid survival to weaning and dam viability from mating to weaning (Zhang et al., 2009).

Estimated heritability in Ettawa Grade goat for 6 mo of age was 0.37 (Table 3). Heritability estimate for 6WM in the present study was higher than those usually in previous study. Boujenane \& El-Hazzab (2008) reported heritability of 6WM used MTDFREML program with range of $0.11-0.23$. However, this value of $6 \mathrm{WM}$ closely in agreement with data reported by Al Saef, (2013) for Syrian Damascus goat used Multi Traits Derivative Free Restricted Maximum Likelihood program (MTDFREML) was 0.36 . The variations in these literatures may be due to the differences in goat breed, environment and management. Additionally, statistical methods, data structure and sampling error accord to Zhang et al. (2009).

The heritability estimates for $12 \mathrm{WM}$ and $18 \mathrm{WM}$ were 0.68 and 0.63 respectively. Heritability in this study was lower than the value obtained by Bosso et al. (2007) on Dwarf goat was 0.73. Nevertheless, these estimates are higher than the value obtained by several authors Zhang et al. (2009) on Boer goat, Ozcana et al. (2005) on Turkish Merino sheep, Safari et al. (2005) on sheep and Gizawa et al. (2007) on Menz sheep. Result of heritability $12 \mathrm{WM}$ in this study was high, it was expected that selection on growth trait was effective. High heritability value of $12 \mathrm{WM}$ and $18 \mathrm{WM}$ suggest that selection on the basis of individual performance will effective in achieving increased gain in 12WM and 18WM.

Repeatability. Estimates of repeatability of BW, WW, $6 \mathrm{WM}, 12 \mathrm{WM}$, and $18 \mathrm{WM}$ were $0.98 \pm 0.01 ; 0.97 \pm 0.01$; $0.94 \pm 0.03 ; 0.71 \pm 0.12$ and $0.91 \pm 0.04$, respectively. The re-

Table 3. Estimated heritability and standard errors for BW, WW, $6 \mathrm{WM}, 12 \mathrm{WM}$ and 18WM for Ettawa Grade goat

\begin{tabular}{llllll}
\hline Traits & $\begin{array}{l}\text { Number } \\
\text { of animal }\end{array}$ & $h^{2} \pm$ SE & VA & VE & VP \\
\hline BW & 316 & $0.54 \pm 0.12$ & 0.022 & 0.175 & 0.197 \\
WW & 316 & $0.35 \pm 0.07$ & 0.034 & 1.534 & 1.568 \\
$6 W M$ & 259 & $0.37 \pm 0.09$ & 3.579 & 6.063 & 9.642 \\
12WM & 259 & $0.68 \pm 0.16$ & 3.846 & 28.132 & 31.978 \\
18WM & 165 & $0.63 \pm 0.19$ & 0.012 & 15.743 & 15.755 \\
\hline
\end{tabular}

Note: $\mathrm{BW}=$ growth traits at birth, $\mathrm{WW}=$ growth traits at weaning, $6 \mathrm{WM}=$ growth traits at $6 \mathrm{mo}, 12 \mathrm{WM}=$ growth traits at $12 \mathrm{mo}, 18 \mathrm{WM}=$ growth traits at $18 \mathrm{mo}$. 
peatability estimated for body weight traits were high range from 0.71 to 0.98 are presented in Table 4 . Repeatability in this study was higher than the value obtained by several studies in diffrent goat breeds (Gifford et al., 1991; Snyman \& Olivier 1999). Gifford et al. (1991) reported repeatability of body weight were 0.62 and 0.18 , respectively. High repeatability values of all growth traits in Ettawa grade goat suggest that a relatively large contribution of additive genetic variance and potentiality of improving body weight in goats by selection. Difference in reproductive status of the does could most probably have contributed to the low estimated repeatability of body weight (Snyman \& Olivier, 1999).

Genetic and phenotypic correlations. Genetic and phenotypic correlations among the traits studies are presented in Table 5. Genetic correlations between all body weight traits in this study ranged from between 0.03 for BW and $12 \mathrm{WM}$ and 0.87 for $12 \mathrm{WM}$ and 18WM. Genetic correlations among weight measurements were low to high and range from 0.19 to 0.92 (Bosso et al., 2007; Zhang et al., 2008; Wang et al., 2011). The genetic correlations between all traits of growth traits in this study were consistently low to high and positive. The positive genetic correlations existing between body weight traits indicate that genetic improvement in any one of the traits could be made through indirect selection for correlated traits (Boujenane \& El-Hazzab, 2008). In this study, BW had low correlations with the remaining variables ranging from 0.03 to 0.35 for genetic correlations. This result corresponds well with Bosso et al. (2007) and Al-Saef (2013) who reported

Table 4. Estimated repeatability and standard errors for BW, WW, 6WM, 12WM and 18WM for Ettawa Grade goat

\begin{tabular}{lcc}
\hline Traits & Number of animal & $\mathrm{R} \pm \mathrm{SE}$ \\
\hline BW & 28 & $0.98 \pm 0.01$ \\
WW & 28 & $0.97 \pm 0.01$ \\
$6 \mathrm{WM}$ & 23 & $0.94 \pm 0.03$ \\
$12 \mathrm{WM}$ & 26 & $0.71 \pm 0.12$ \\
$18 \mathrm{WM}$ & 21 & $0.91 \pm 0.04$ \\
\hline
\end{tabular}

Note: $\mathrm{BW}=$ growth traits at birth, $\mathrm{WW}=$ growth traits at weaning, $6 \mathrm{WM}=$ growth traits at $6 \mathrm{mo}, 12 \mathrm{WM}=$ growth traits at $12 \mathrm{mo}, 18 \mathrm{WM}=$ growth traits at $18 \mathrm{mo}$

Table 5. Estimated of genetic correlations (below diagonal) and phenotypic correlations (above diagonal) among body weights for Ettawa Grade goat

\begin{tabular}{lccccc}
\hline & BW & WW & 6 WM & $12 W M$ & $18 W M$ \\
\hline BW & & 0.169 & 0.298 & 0.084 & 0.232 \\
WW & 0.349 & & 0.689 & 0.653 & 0.642 \\
6WM & 0.044 & 0.644 & & 0.83 & 0.744 \\
12WM & 0.033 & 0.708 & 0.766 & & 0.926 \\
18WM & 0.149 & 0.547 & 0.590 & 0.872 & \\
\hline
\end{tabular}

Note: $\mathrm{BW}=$ growth traits at birth, $\mathrm{WW}=$ growth traits at weaning, $6 \mathrm{WM}=$ growth traits at $6 \mathrm{mo}, 12 \mathrm{WM}=$ growth traits at $12 \mathrm{mo}, 18 \mathrm{WM}=$ growth traits at $18 \mathrm{mo}$
BW had lower genetic correlation. In the contrary, Boujenane \& El-Hazzab (2008) reported that BW had higher genetic correlation on Draa goats. The estimate of genetic correlation between WW and 12WM in this study was high (0.71) and this implies that WW is a good indicator of subsequent development of the kid. The genetic correlation estimates in this study correspond well with Bosso et al. (2007) who reported genetic correlation for WW and W360 for Dwarf goat of 0.74 . The reason of different estimates could be due to the fact that all estimates depend on the models that were utilized as well as the random factors (Zishiri et al., 2009). The high and positive genetic correlations between WW and 12WM traits in this study implies that they are all being controlled by similar genes and thus selection for any one of these traits would lead to positive changes in the other.

The phenotypic correlations ranging from 0.08 between BW and 12WM to 0.93 between 12WM and $18 \mathrm{WM}$. The genetic correlations between all traits found same trend as the genetic correlations in accordance with previous stud in different goat breeds (Al-Shorepy et al., 2002; Xu et al., 2005; Han et al., 2005; Maxa et al., 2006). Al-Shorepy et al. (2002) obtained that genetic and phenotypic correlations between BW, 1WM and 3WM of age were positive (0.45-0.99). These low correlations between BW and 12WM are favourable because selection for traits like pre-weaning weight is not expected to have an effective correlated response in birth weight. Heavier kids at birth were not able to express their potential for growth (Mugambi et al., 2007). However, the estimate of phenotypic correlation between WW and 12WM in this study was high (0.65) indicated a strong positive relationship between the two traits. These results were consistent with that reported by Bosso et al. (2002) were still positive indicating that selection for high WW will result in higher $12 \mathrm{WM}$.

\section{Genetic and Phenotypic Trends}

Genetic and phenotypic trends for growth trait including BW, WW, 6WM, 12WM, and 18WM are shown in Figure 1 and 2, respectively. The genetic trends for all growth traits were fluctuating from 2007 to 2011. As illustrated in Figure 1, the genetic trends, the BW rose from 2007 to 2008 and constant until 2009, and after 2009 declined until 2011. The weaning weight (WW) showed after the large decline in 2008, the trends rose considerably at 2009, but after 2009 the trends decline considerably until 2011. There were increased in the genetic trends of 6WM from 2007 to 2009 but declined from 2009 to 2011. The 12WM showed after the large rose in 2008, the trends decreased until 2009. In 2009 the trends decreased considerably at 2010 and decreased until 2011. There were constant in the genetic trends of $18 \mathrm{WM}$ from 2007 to 2008. After the large decline in 2009, the trends in 2010 constant and declined until 2011. This result was in agreement with Bosso et al. (2007) who reported that the fluctuation of genetic trends values were observed for BW, W120 and W360 in Dwarf goat. The genetic trend of BW, WW, 6WM, 12WM, and 18WM were -0.019 ; 0.02; 0.003; 0.009 and $0.005 \mathrm{~kg} /$ year, respectively (Table 6). Bosso et al. (2007) reported that genetic trend for 




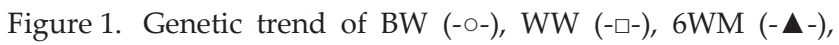
12WM (-x-) and 18WM (- -$)$ for Ettawa Grade goat

BW, W120 and W180 were 0.01; 0.02 and $0.08 \mathrm{~kg} /$ year, respectively. Differences between estimated genetic values for these traits in comparison with other studies in general is due to difference in animal breeding standard and follow that different program selection, difference between models and calculation method and also effects of environmental, interaction between genetic and environmental, nutrition, climate conditions and breed factors (Shaat et al., 2004; Zhang et al., 2009; Yaeghoobi et al., 2011). Irregular fluctuations were observed in yearly mean predicted breeding values for WW, 12WM, and 18WM. The fluctuation of predicted breeding value mean was apparently due to selection sire with low breeding value. It seems that this low selection response implying that introduction of outside sire was base and phenotypic characteristics.

As illustrated in Figure 2, the phenotypic trends BW and WW traits generally showed a constant from 2007 to 2011. After the small declined in 2008, the trends for 6WM in 2009 to 2010 small rose and declined until 2011. The phenotypic trends of 12WM and 18WM traits decreased from 2007 to 2008, but in 2009 the trends were increased and in 2009 until 2011 decreased considerably. The phenotypic trends of all growth traits generally were negative for all studies trait. The phenotypic trend for BW, WW, 6WM, 12WM, and 18WM were -0.02; -0.53; $-1.11 ;-2.23$ and $-5.18 \mathrm{~kg} /$ year, respectively (Table 6). The phenotypic $6 \mathrm{WM}, 12 \mathrm{WM}$, and $18 \mathrm{WM}$ were fluctuating from 2007 to 2011. The trends of $6 \mathrm{WM}, 12 \mathrm{WM}$, and $18 \mathrm{WM}$ in 2008 decreased and thereafter increased in 2008 to 2010; 2008 to 2009 and 2008 to 2009 respectively. The trends of 12WM and 18WM in 2009 to 2011 rose considerably. The reduction for calve born 6WM in 2008; 12WM and 18WM in 2008 and 2009 to 2011 were mainly due to a larger proportion of calves selected in previous years in order to increase the population for selected sire and dams. Phenotypic performance in $6 \mathrm{WM}, 12 \mathrm{WM}$ and 18WM could be improved also through management strategies. Changes in management such as grazing strategies, pasture improvement and culling procedures needed to be monitored in order to evaluate the benefit of change (Intaratham et al., 2008). Body weight showed no definite trend that indicated low degree of $\mathrm{R}^{2}$ except

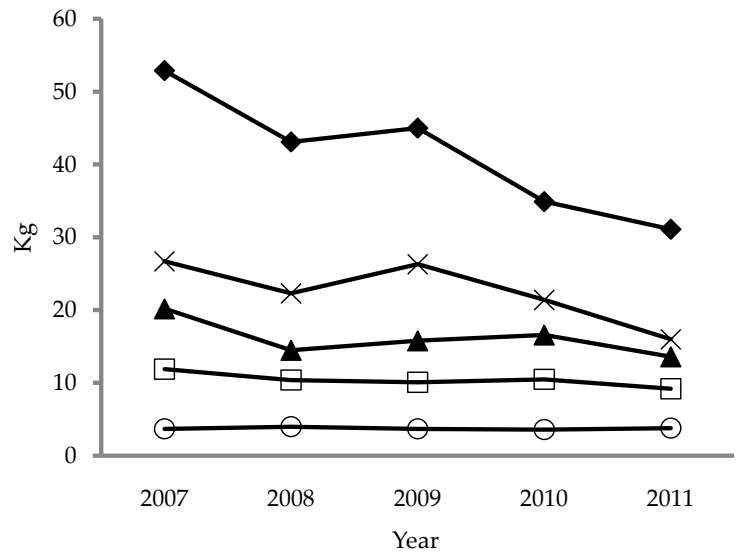

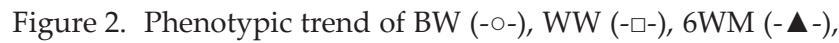
12WM (-x-) and 18WM (- -$)$ for Ettawa Grade goat

Table 6. Genetic and phenotypic trends of body weight for Ettawa grade goat

\begin{tabular}{llc}
\hline & Regression equation & R2 \\
\hline Genetic trend & EBV BW $=0.02-0.019 x$ & 16.3 \\
& EBV WW $=0.06-0.02 x$ & 59.4 \\
& EBV 6WM $=-0.01+0.003 x$ & 41.3 \\
& EBV 12WM $=-0.03+0.009 x$ & 69.4 \\
& EBV 18WM $=0.019+0.005 x$ & 78.7 \\
Phenotypic trend & BW $=3.82-0.02 x$ & 15.3 \\
& WW $=12.0-0.53 x$ & 74.2 \\
& $6 \mathrm{WM}=19.5-1.11 x$ & 47.5 \\
& $12 W M=29.2-2.23 x$ & 65.8 \\
& $18 W M=56.9-5.18 x$ & 90.5 \\
\hline
\end{tabular}

Note: $\mathrm{BW}=$ growth traits at birth, $\mathrm{WW}=$ growth traits at weaning, $6 \mathrm{WM}=$ growth traits at $6 \mathrm{mo}, 12 \mathrm{WM}=$ growth traits at $12 \mathrm{mo}, 18 \mathrm{WM}=$ growth traits at $18 \mathrm{mo}$

18WM for genetic and phenotypic trend. The low degree of genetic progress for body weight can be explained mainly by selection program and this may slow down genetic progress (Gunawan et al., 2011).

\section{CONCLUSION}

High and positive genetic correlations between all growth traits and $12 \mathrm{WM}$ traits in this study indicated that selection for high $12 \mathrm{WM}$ will improve genetic merit in Ettawa Grade goats.

\section{ACKNOWLEDGEMENT}

The authors greatly acknowledge the Breeding Centre BPTU-HPT Pelaihari in South Kalimantan which support and provide the full data of this research. The authors would like to express our thanks to Indonesian Ministry of Education and Culture, Directorate General of Higher Education for Beasiswa Unggulan 2012. 


\section{REFERENCES}

Al-Saef. 2013. Genetic and phenotypic parameters of body weights in Saudi Aradi goat and their crosses with Syrian Damascus goat. Small Rumin. Res. 112: 35-38. http:// dx.doi.org/10.1016/j.smallrumres.2012.12.021

Al-Shorepy, S. A., G. A. Alhadrami., \& K. Abdulwahab. 2002. Genetic and phenotypic parameters for early growth traits in Emirati goat. Small Rumin. Res. 45: 217-223. http:// dx.doi.org/10.1016/S0921-4488(02)00110-4

Atabany, A., I. K. Albdulgani., A. Sudono., \& K. Mudikdjo. 2001. Performa produksi, reproduksi dan nilai ekonomis kambing Peranakan Ettawa di peternakan Barokah. Med. Pet. 24: 1-7.

Baneh, H. \& S. H. Hafezian. 2009. Effect of environmental factor on growth traits in Ghezel sheep. Afr. J. Biotechnol. 8: 2903-2907.

Becker, W. A. 1992. Manual of Quantitative Genetics, $5^{\text {th }}$ ed. Academic Enterpries., USA.

Bosso, N. A., M. F. Cisse., E. H. van der Waaij., A. Fall, \& J. A. M. van Arendonk. 2007. Genetic and phenotypic parameters of body weight in West African Dwraf goat and Djallonke sheep. Small Rumin. Res. 67: 271-278. http://dx.doi. org/10.1016/j.smallrumres.2005.11.001

Boujenane, I \& A. El Hazzab. 2008. Genetic parameters for direct and maternal effect on body weights of Draa goats. Small Rumin. Res. 80: 16-21. http://dx.doi.org/10.1016/j.sm allrumres.2008.07.026

Browning, Jr. R., S. H. Kebe, \& M. Byars. 2004. Preliminary assement of Boer and Kiko does as maternal lines for kid performance under humid, subtropical conditions. S. Afr. J. Anim. Sci. 34: 1-3.

Direktorat Jenderal Peternakan. 2013. Populasi Kambing Menurut Propinsi. http://www.deptan.go.id [2 Maret 2014].

Filho, R. A. T., R. A. Torres., P. S. Lopes., C. S. Pereira., R. F. Euclydes., C. V. Araujo \& M. A. Silva. 2005. Genetics trends in performance and reproductive traits of pigs. Genet. Mo. Biol. 28: 97-102. http://dx.doi.org/10.1590/S141547572005000100017

Gifford, D. R., R. W. Ponzoni., R. J. Lampe, \& J. Burr. 1991. Phenotypic and genetics parameters of flece traits and live weight in South Australian Angora goats. Small. Rumin. Res. 4: 293-302. http://dx.doi.org/10.1016/09214488(91)90153-H

Gizawa, S., Lemma., Sisay., Komenb., Hans., A. M. Johan, \& van Arendonk. 2007. Estimates of genetic parameters and genetic trend for live weight and fleece traits in Menz sheep. Small Rumin. Res. 70: 113-153.

Gunawan, A. \& R. R. Noor. 2006. Estimation heritability of birth and weaning weight of the fighting type of Garut sheep. Med. Pet. 29: 7-15.

Gunawan, A., R. Sari, \& Y. Parwoto. 2011. Genetic analysis of reproductive traits in Bali cattle maintaned on range under artificially and naturally bred. J. Indonesian Trop. Anim. Agric. 3:152-158.

Haile, A., B. K. Joshi., W. Ayalew., A. Tegeg, \& A. Singh. 2009. Genetic evaluation of Ethiopian Boran cattle and their crosses with Holstein Frisien in central Ethiopia; reproductive traits. J. Agric. Sci. 147 :81-89. http://dx.doi.org/10.1017/ S0021859608008095

Hammoud, M. H., S. Z. El-Zarkounyl, \& E. Z. M. Qudah. 2010. Effect of sire, age at first calving, seadon and year of calving and parity on reproductive performance of Friesian cows under semiarid conditions in Egypt. Arch. Zootech. $13: 60-82$.

Han, W. J., T. Feng., J. J. An, \& Y. L. Chen. 2005. Analysis on comparison of body weight for different hybrid weaned lamb. Acta Ecologiae Animalis Domastici. 26 : 43-45.
Intaratham, W., S. Koonawootrittriton., P. Sopannarath., H. U. Graser, \& S. Tumwasorn. 2008. Genetic parameters and annual trends for birth and weaning weights of a northeastern Thai indigenous cattle line. Asian-Aust. J. Anim. Sci. 21: 478-483.

Liu, K., Y. Zhang, \& Z. Zhou. 2005. Adjusment for non-genetic effects on body weight and size in Angora goats. Small Rumin. Res. 59: 25-31. http://dx.doi.org/10.1016/j.smallrum res.2004.11.006

Mandal, A., F. W. C. Neser., P. K. Rout., R. Roy, \& D. R. Notter. 2006. Estimation of direct and maternal (co)variance components pre-weaning growth traits in Muzaffarnagari sheep. Livest. Sci. 99: 79-89. http://dx.doi.org/10.1016/ j.livprodsci.2005.06.001

Meyer, K. 1992. Variance components due to direct and maternal effect for growth traits of Australian beef cattle. Livest. Prod. Sci. 31: 179-204. http://dx.doi.org/10.1016/03016226(92)90017-X

Mioč, B., V. Susič., Z. Antunovič., Z. Prpič., I. Vnučec, \& A. Kasap. 2011. Study on birth weight and pre-weaning growth of Croation multicolored goat kids. Veterinarski Archiv. 81: 339-347.

Mokhtari, M. S. \& A. Rashidi. 2010. Genetic trends estimation for body weight of Kermani sheep at different age using multivariate animal models. Small Rumin. Res. 88: 23-26. http://dx.doi.org/10.1016/j.smallrumres.2009.11.003

Mugambi, J. N., J. W. Wakhungu., B. O. Inyangala., W. B. Muhuyi., T. Muasya. 2007. Evaluation of the performance of the Kenya Dual Purpose Goat composites: additive and non-additive genetic parameter. Small Rumin. Res. 72: 149156. http://dx.doi.org/10.1016/j.smallrumres.2006.10.001

Ozcana, M., B. Ekiza., A. Yilmaza, \& A. Ceyhanb. 2005. Genetic parameter estimates for lamb growth traits and greasy fleece weight at first shearing in Turkish Merino sheep. Small Rumin. Res. 56: 215-222. http://dx.doi.org/10.1016/ j.smallrumres.2004.06.009

Rashidi, A., S. C. Bishop, \& A. Matika. 2011. Genetic parameter estimates for pre-weaning performance and reproduction traits in Markhoz goats. Small Rumin. Res. 100: 100-106. http://dx.doi.org/10.1016/j.smallrumres.2011.05.013

Safari, E., N. M. Fogarty, \& A. R. Gilmour. 2005. A review of genetic parameter estimates for wool, growth, meat and reproduction traits in sheep. Livest. Prod. Sci. 92: 271-289. http://dx.doi.org/10.1016/j.livprodsci.2004.09.003

Shaat, I., S. Galal, \& H. Mansour. 2004. Genetics trends for lamb weight in flocks of Egyptian Rahmani and Ossimi sheep. Small Rumin. Res. 51:23-28. http://dx.doi.org/10.1016/ S0921-4488(03)00185-8

Shrestha, J. N. B \& M. H. Fahmy. 2007. Breeding goats for meat production: a review: 3. Selection and breeding strategies. Small Rumin. Res. 67:113-125. http://dx.doi.org/10.1016/ j.smallrumres.2005.05.040

Synman, M. A \& J. J. Olivier. 1999. Repeatability and heritability of objective and subjective fleece traits and body weight in South African Angora goats. Small Rumin. Res. 34:103109. http://dx.doi.org/10.1016/S0921-4488(99)00063-2

Sodiq, A. 2005. Doe productivity of Kacang and Peranakan Ettawa goats and factor affecting them in Indonesia. J. Agric. Rural Dev. Tropics Subtropics. Beihet (Supplement) 78: 1121.

Sodiq, A \& Z. Abidin. 2010. Meningkatkan Produksi Kambing Peranakan Ettawah. Cetakan ketiga. Penerbit Agro Media Pustaka, Jakarta. 128 halaman.

Sodiq, A. 2012. Non genetic factors affecting pre-weaning weight and growth rate of Ettawa Grade goats. Med. Pet. 35: 21-27. http://dx.doi.org/10.5398/medpet.2012.35.1.21

Steel R. G. D \& J. H. Torrie. 1995 Prinsip dan Prosedur Statistika. Penerjemah: Sumantri B. Ed ke-4. Jakarta: Gramedia. 
Valencia, M., J. Dobler, \& H. H. Montaldo. 2007. Genetic and phenotypic parameters for lactation traits in a flock of Saanen goats in Mexico. Small Rumin. Res 68: 318-322. http:// dx.doi.org/10.1016/j.smallrumres.2005.11.017

Vargas, S., A. Larbi, \& M. Sanchez. 2007. Analysis of size and conformation of native Creole goat breeds and crossbreds in smallholders agrosilvopastoral system in Puebla Mexico. Trop. Anim. Health Prod. 39: 279-286. http://dx.doi. org/10.1007/s11250-007-9012-6

Wang, D. H., G. Y. Xu., D. J. Wu, \& Z. H. Liu. 2011. Characteristic and production performance of Tianfu goat, a new breed population. Small Rumin. Res. 95: 88-91. http:// dx.doi.org/10.1016/j.smallrumres.2010.10.010

Wenzhong, L.,cY. Zhang., \& Z. Zhou. 2005. Adjustment for nongenetic effects on body weight and size in Angora goats. Small Rumin. Res. 95: 25-31.

Xu, T. S., D. J. Wang., X. L. Liu., G. Y. Hou., W. L. Xia, \& X. Z. Huang. 2005 .Genetic parameters and trends of milk and fat yield in Holsteins dairy cattle of West Province of Iran. Int. J. Dairy. Sci. 6: 142-149.
Yaeghoobi, R., A. Doosti., A. M. Noorian \& A. M. Bahrami. 2011. A research on path analysis and optimum regression equation between body size and body weight of Hainan Black Goat. Acta Ecologiae Animalis Domastici. 1: 49-53.

Zhang, C., L. Yang, \& S. Zhong. 2008. Variance components and genetic parameters for weight and size at birth in the Boer goat. Livest. Sci. 115: 73-79. http://dx.doi.org/10.1016/ j.livsci.2007.06.008

Zhang, C. Y., Y. Zhang., D. Q. Xu., X. Li., J. Su, \& L. G. Yang. 2009. Genetic and phenotypic estimates for growth traits in Boer goat. Livest. Sci. 124: 66-71. http://dx.doi.org/10.1016/ j.livsci.2008.12.010

Zhou, H.M., D. Allain., J. Q. Li., W. G. Zhang, \& X. C. Yu. 2003. Effect of non-genetic factors on production traits of Inner Mongolia cashmere goats in China. Small Rumin. Res. 47: 85-89. http://dx.doi.org/10.1016/S0921-4488(02)00246-8

Zishiri, O. T., S. W. P. Cloete, J. J. Olivier \& K. Dzama. 2010. Genetic trends in South African terminal sire sheep breeds. S. Afr. J. Anim. Sci. 1: 450-458. 